Int. J. Morphol.,

34(1):13-16, 2016.

\title{
Morphologic and Morphometric Analysis of the Ovary of Black Bengal Goat (Capra hircus)
}

\author{
Análisis Morfológico y Morfométrico del Ovario de la Cabra Black Bengal (Capra hircus)
}

\author{
Ziaul Haque*; Azimul Haque** \& Md. Abul Quasem***
}

\begin{abstract}
HAQUE, Z.; HAQUE, A. \& QUASEM, M. A. Morphologic and morphometric analysis of the ovary of black Bengal goat (Capra hircus). Int. J. Morphol., 34(1):13-16, 2016.

SUMMARY: Ovary plays the vital role in the reproductive biology and biotechnology of female animals. With the aim to study the ovarian morphometry of Black Bengal goat, both right and left ovaries were collected from the slaughter houses of different Thanas under Mymensingh district. For each of the specimens, gross parameters such as weight, length and width were recorded. Then they were processed and stained with $\mathrm{H} \& \mathrm{E}$ for histomorphometry. Our study revealed that the right ovary $(0.53 \pm 0.02 \mathrm{~g})$ was heavier than the left $(0.52 \pm 0.02 \mathrm{~g})$. The length of the right ovary $(1.26 \pm 0.04 \mathrm{~cm})$ was lower than the left $(1.28 \pm 0.02 \mathrm{~cm})$ but the width of the right $(0.94 \pm 0.02 \mathrm{~cm})$ was greater than the left $(0.90 \pm 0.03 \mathrm{~cm})$. The diameter of ovarian follicles in the cortex was measured as primordial $39.6 \pm 6.61 \mu \mathrm{m}$, primary single layer $54.0 \pm 4.06 \mu \mathrm{m}$, primary multi layer $147.6 \pm 11.04 \mu \mathrm{m}$, secondary with C-shaped antrum $449.5 \pm 75.71 \mu \mathrm{m}$ and tertiary follicle of ovary $1.3 \pm 0.20$ $\mathrm{mm}$. In the graffian follicle, the thickness of granulosa cell layer was $79.2 \pm 11.04 \mu \mathrm{m}$, theca interna $75.76 \pm 6.82 \mu \mathrm{m}$, theca externa $130.07 \pm 12.53$ $\mu \mathrm{m}$ and the oocyte diameter was $109.8 \pm 5.75 \mu \mathrm{m}$. These results will be helpful to manipulate ovarian functions in small ruminants.
\end{abstract}

KEY WORDS: Morphometry; Ovarian follicles; Cortex; Medulla; Oocyte.

\section{INTRODUCTION}

Black Bengal goat is the national pride of Bangladesh. The most promising prospect of Black Bengal goat in Bangladesh is that this dwarf breed is a prolific breed, required small area to raise and with the advantage of their selective feeding habit with a broader feed range. It is very popular to consumers for its delicious and tender meat. Its skin is also highly valued in the world market due to some unique features of yielding finest leather that is light in weight and fine in texture. Considering the paramount importance and bright prospects of Black Bengal goat in Bangladesh, goat production level should be maintained properly by increasing fertility and conception rate.

Ovary is the key female reproductive organ of all the vertebrates. The reproductive physiology of goat is least understood compared to cattle, sheep and pig. A search of the literature for specific and detailed information on the ovary of goat is not rewarding. Description of goat is usually made as if it is identical with sheep (Smith, 1986). Some work on the morphology, physiology and pathology of reproductive organs of the goat (Epelu-Opio et al., 1988; Moreira, et al., 1991; Sattar \& Khan, 1988; Torres \& Badiongan, 1989) has been reported in many countries. But no comprehensive study has yet been undertaken on the ovary of Black Bengal goat in Bangladesh. Therefore, the study was designed to clarify the morphology and morphometry of the ovary of Black Bengal goat. The knowledge of the present study will contribute significantly in the reproductive biology and biotechnology of small ruminants.

\section{MATERIAL AND METHOD}

The study was conducted in the laboratory of the Department of Anatomy and Histology, Faculty of Veterinary Science, Bangladesh Agricultural University, Mymensingh, Bangladesh.

Collection and transportation of ovaries. Both right \& left ovaries of the female non-gravid adult Black Bengal goats (1-2 years of age) were collected from the slaughter houses of different Thanas under Mymensingh district. The ovaries were then kept in collection vial containing $0.9 \%$

* Associate Professor, Department of Anatomy and Histology, Faculty of Veterinary Science, Bangladesh Agricultural University, Mymensingh, Bangladesh.

*** Research student, Chittagong Veterinary and Animal Sciences University, Chittagong, Bangladesh.

**** Professor, Department of Anatomy and Histology, Faculty of Veterinary Science, Bangladesh Agricultural University, Mymensingh, Bangladesh. 
physiological saline in a thermo flask at $25{ }^{\circ} \mathrm{C}$ to $30{ }^{\circ} \mathrm{C}$ and transported to the laboratory within 4 to $5 \mathrm{~h}$ of slaughter. The ovaries were then transferred to sterilize Petri dishes and rinsed thoroughly by physiological saline at $25^{\circ} \mathrm{C}$ before further processing.

Measurement of weight, length and width. After trimming individually, the right and left ovaries were weighed with the help of an electric balance. The length and width were measured with the help of measuring scale.

Histomicrometry. The ovarian tissues were fixed by Bouin's fixative for 4 hours and then processed for routine paraffin embedding technique. The paraffin sections were cut by microtome $(5-6 \mu \mathrm{m})$ and stained with routine Hematoxylin and Eosin (H \& E) for histomorphometrical analysis. The diameter of ovarian follicles and thickness of follicular layers along with oocyte diameter were measured by micrometry methods.

Data analysis. All the data were recorded in a tabular form and analyzed by Student's t-test.

\section{RESULTS AND DISCUSSION}

Gross study of the ovary. The ovaries were found almondshaped, pale colored structures situated in the edge of the mesovarium near the lateral margin of the pelvic inlet. This report corresponds the report of Sisson et al. (1975) and May (1970). Each ovary had an irregular surface by follicles of various sizes projecting from the surface. It also supports their observations. The weight, length and width of the left

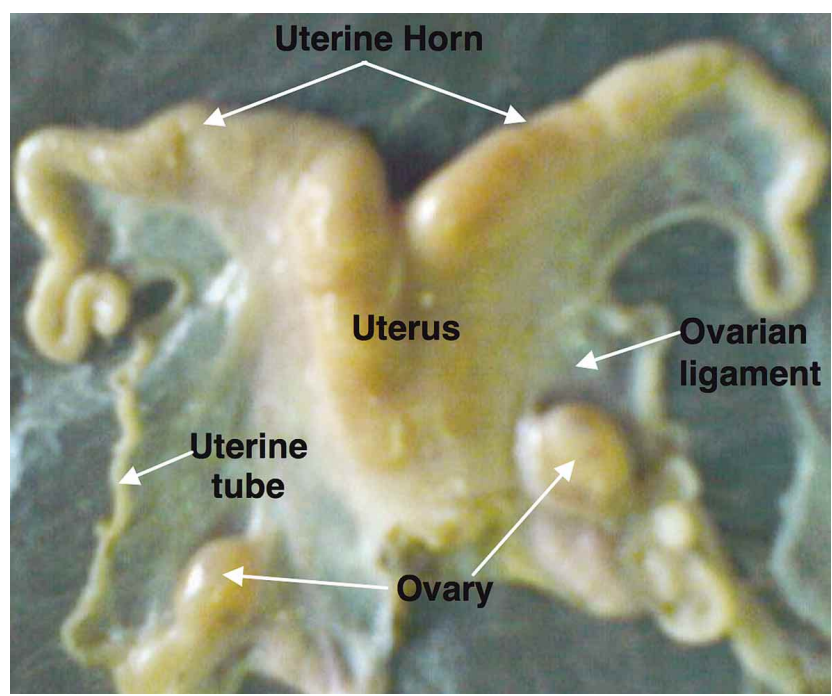

Fig. 1. Photograph of the ovary and its associated structures of adult (2 years of age) Black Bengal goat. ovary were $0.52 \pm 0.02 \mathrm{~g}, 1.28 \pm 0.02 \mathrm{~cm}$ and $0.90 \pm 0.03 \mathrm{~cm}$ and of the right were $0.53 \pm 0.02 \mathrm{~g}, 1.26 \pm 0.04 \mathrm{~cm}$ and $0.94 \pm 0.02 \mathrm{~cm}$, respectively. The length of the left and right ovaries were $1.71 \pm 0.27 \mathrm{~cm}$ and $1.73 \pm 0.27 \mathrm{~cm}$, respectively in Nigerian goats (Adigwe \& Fayemi, 2005); $1.5 \mathrm{~cm}$ reported for small ruminants ( $S i s s o n$ et al.); $2.2 \mathrm{~cm}$ reported in goats (Smith). The uterine extremity of the ovaries was connected with the extremity of the horn of uterus by proper ligament of the ovary. There was no demarcation between the horn of the uterus and the very flexuous uterine tubes (Fig. 1).

Microscopic study of the ovary. The ovary consisted of two distinct zones, peripheral cortex and central medulla. This report is in agreement with Dellmann (1971) and Banks (1986).

\section{A. Ovarian Cortex.}

Germinal epithelium: The ovary was covered by a surface epithelium of simple squamous to low cuboidal epithelial cells. This result differs from the reports of Dellmann and Mohammadpour (2007).

Tunica albuginea: Underlying the surface epithelium was a capsule of dense irregular connective tissue.

Follicles: Follicles of various stages of development were found in the cortex surrounded by the stroma. They were distinguished as:

I.Primordial follicles: They were located immediately beneath the tunica albuginea. Each was found to contain an oocyte with a large nucleus lined by simple squamous epithelium in contact with the smooth surface of the oocyte (Fig. 2A). The diameter of primordial follicle was 39.6 66.61 $\mu \mathrm{m}$. It differs from the reports of Adigwe \& Fayemi and Mohammadpour.

II. Growing follicles: The growing follicles were found into the deep layers of the cortex. In primary follicles, the follicular cells were found to columnar with alteration of primary oocyte. The diameter of primary follicle, single and multi layer were $54.0 \pm 4.06 \mu \mathrm{m}$ and $147.6 \pm 11.04 \mu \mathrm{m}$, respectively (Fig. 2B and 2C). The secondary follicles were identified by an increase in follicular cell population associated with the primary oocyte and development of zona pellucida between primary oocyte and follicular cells (Fig. 2D). The stromal cells differentiated into theca interna and externa. The thecal cells were separated by a basement membrane. The theca interna consisted of large, epitheloid cells and an extensive vascular network. The theca externa was fibroelastic layer of cells. The diameter of secondary follicle with C-shaped antrum was found as $449.5 \pm 75.71$ 

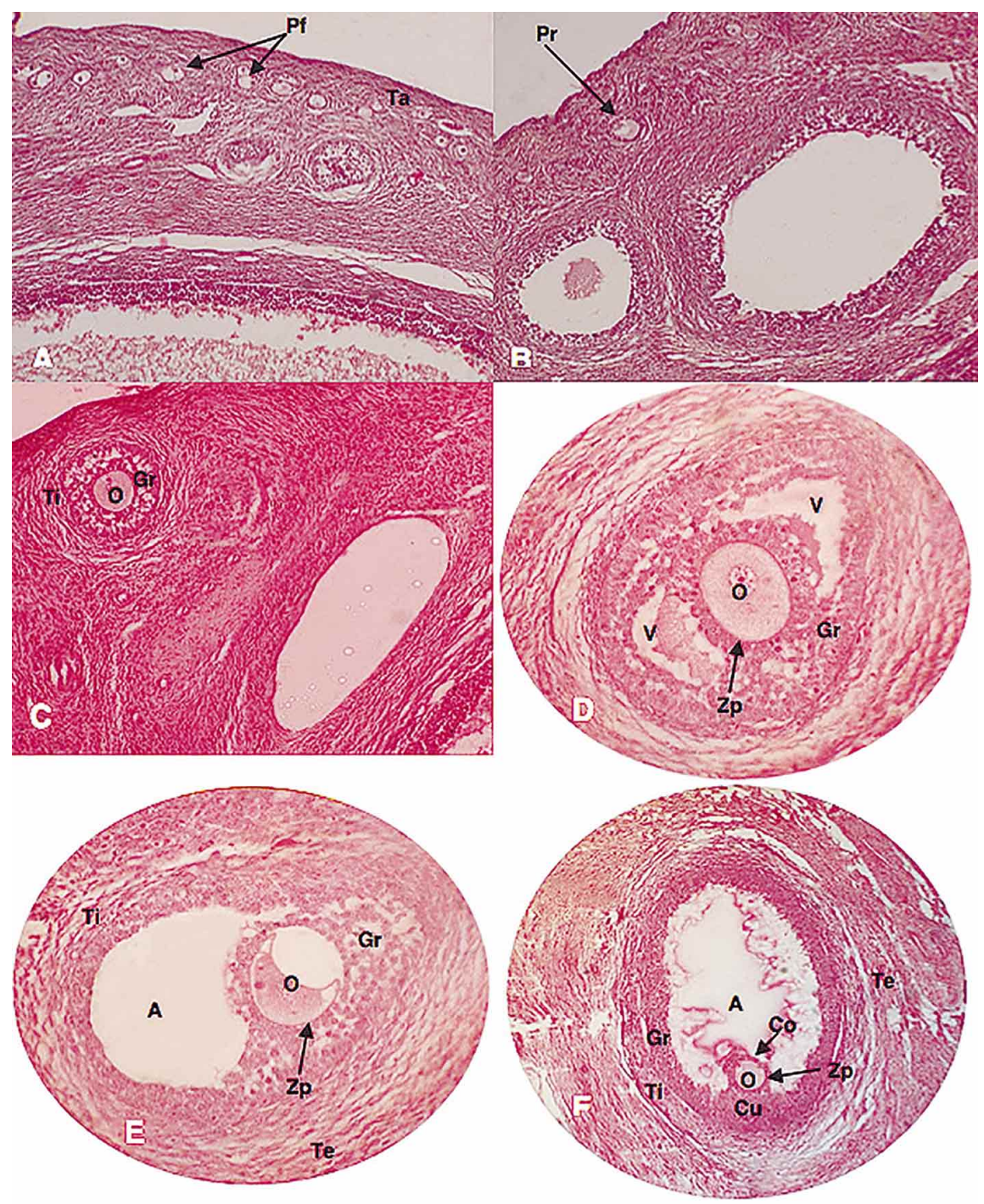

Fig. 2. Photographs showing ovarian follicles in the cortex (H \& E). A). Primordial follicle X10. B). Primary follicle (single layer) X10. C). Primary follicle (multilayer) X10. D). Secondary (vesicular) follicle X40. E). Secondary follicle with C-shaped antrum X40. F). Tertiary follicle of ovary $\mathrm{X} 40 . \mathrm{Pf}=$ Primordial follicle, $\mathrm{Pr}=$ Primary follicle, $\mathrm{Ta}=$ Tunica albuginea, $\mathrm{Gr}=\mathrm{Granulosa}$ cells, $\mathrm{Zp}=\mathrm{Z}$ ona pellucida, $\mathrm{Co}=$ Corona radiata, $\mathrm{Cu}=\mathrm{Cumulus}$ oophorus, $\mathrm{O}=$ Oocyte, $\mathrm{V}=$ Vesicle, $\mathrm{A}=$ Antrum, $\mathrm{Ti}=$ Theca interna, $\mathrm{Te}=$ Theca externa.

Fig. 3. Photograph of medulla in the ovary of Black Bengal goat $(\mathrm{H} \&$ E) $\mathrm{X} 10 . \mathrm{Bv}=\mathrm{Blood}$ vessels, $\mathrm{CT}=$ Connective tissue.

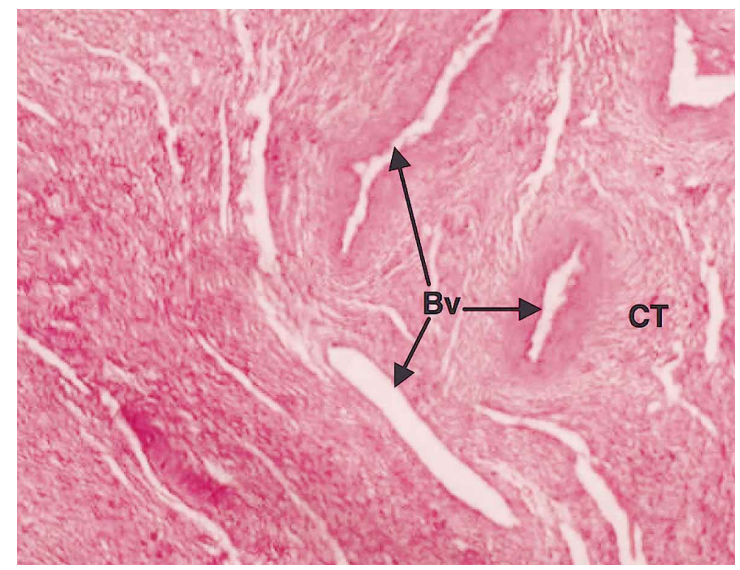

$\mu \mathrm{m}$ (Fig. 2E). The diameter of primary and secondary follicles also differ from the reports of Adigwe \& Fayemi and Mohammadpour.

III. Tertiary follicle of ovary: This is accompanied by the continued growth of the follicle. The primary oocyte was still surrounded by a cluster of granulosa cells that was continuous with the peripherally displaced membrane granulosa. The mound of cells was cumulus oophorus. The granulosa cells immediately adjacent to the primary oocyte found columnar that were oriented radially known as corona radiata. The cells of the cumulus oophorus constituted a visceral layer of granulosa cells separated by follicular antrum from the parietal layer of granulose cells. The parietal layer was separated from the theca interna by a basement membrane. This preovulatory follicle was the tertiary or mature follicle (Fig. 2F) which extended from a protrusion at the surface to the depths of the cortex. In the tertiary follicle of ovary, the thickness of granulosa cell layer was $79.2 \pm 11.04 \mu \mathrm{m}$, theca interna $75.76 \pm 6.82 \mu \mathrm{m}$ and theca externa $130.07 \pm 12.53 \mu \mathrm{m}$ where as the oocyte diameter was $109.8 \pm 5.75$ $\mu \mathrm{m}$. The diameter of ovarian follicles and thickness of tertiary follicle of ovary layers (granulosa, theca interna and theca externa) along with oocyte diameter differ from the Iranian (Mohammadpour) and Nigerian native goats (Adigwe \& Fayemi).

\section{B. Ovarian Medulla}

The medulla consisted of dense irregular connective tissue with extensive network of vessels and nerves (Fig. 3). This result support May, Dellmann and Banks. 


\section{AKNOWLEDGEMENTS}

The author wishes great thanks to University Grants Commission (UGC) of Bangladesh for financial support during the study period.

HAQUE, Z.; HAQUE, A. \& QUASEM, M. A. Análisis morfológico y morfométrico del ovario de la cabra Black Bengal (Capra hircus). Int. J. Morphol., 34(1):13-16, 2016.

RESUMEN: El ovario desempeña un papel fundamental en la biología de la reproducción y la biotecnología de las hembras. Con el objetivo de estudiar la morfometría de ovario de la cabra Black Bengal se obtuvieron ovarios de ambos lados de diferentes mataderos del distrito de Mymensingh. Para cada uno de los especímenes, se registraron los parámetros de peso, longitud y ancho. Luego fueron procesados y teñidos con $\mathrm{H} \& \mathrm{E}$ para histomorfometría. El ovario derecho $(0,53 \pm 0,02 \mathrm{~g})$ fue más pesado que el izquierdo $(0,52 \pm 0,02 \mathrm{~g})$. La longitud del ovario derecho $(1,26 \pm 0,04 \mathrm{~cm})$ fue inferior al izquierdo $(1,28 \pm 0,02 \mathrm{~cm})$, pero el ancho del derecho $(0,94 \pm 0,02 \mathrm{~cm})$ fue mayor que el izquierdo $(0,90 \pm 0,03 \mathrm{~cm})$. El diámetro de los folículos ováricos en la corteza se midió como primordial $39,6 \pm 6,61 \mu \mathrm{m}$, de una capa primaria $54,0 \pm 4,06 \mu \mathrm{m}$, de múltiples capas primarias $147,6 \pm 11,04 \mu \mathrm{m}$, secundarias con antro en forma de C $449,5 \pm 75,71 \mu \mathrm{m}$ y folículo terciario del ovario 1,3 $\pm 0,20 \mathrm{~mm}$. En el folículo terciario del ovario, el espesor de la capa de células de la granulosa fue 79,2 $\pm 11,04 \mu \mathrm{m}$, teca interna $75,76 \pm 6,82 \mu \mathrm{m}$, teca externa $130,07 \pm 12,53 \mu \mathrm{m}$ y el diámetro de los ovocitos fue $109,8 \pm 5,75 \mu \mathrm{m}$. Estos resultados serán útiles para manipular las funciones de ovario en los pequeños rumiantes.

PALABRAS CLAVE: Morfometría; Folículos ováricos; Corteza; Médula; Ovocitos.

\section{REFERENCES}

Adigwe, P. I. \& Fayemi, O. A biometric study of the reproductive tract of the red sokoto (Maradi) goats of Nigeria. Pak. Vet. J., 25(3):149-50, 2005.

Banks, W. J. Applied Veterinary Histology. $2^{\text {nd }}$ ed. Baltimore, Williams \& Wilkins, 1986.

Dellmann, H. D. Veterinary Histology: An Outline Text-Atlas. Philadelphia, Lea \& Febiger, 1971.

Epelu-Opio, J.; Weyrauch, K. D. \& Amongi, T. Fine structure of the oviductal epithelium in pregnant local Ugandan goat. $Z$. Mikrosk. Anat. Forsch., 102(6):977-84, 1988.

May, N. D. S. The Anatomy of the Sheep. A Dissection Manual. $3^{\text {rd }}$ ed. St. Lucia, University of Queensland Press, 1970.
Mohammadpour, A. A. Comparative histomorphological study of ovary and ovarian follicles in Iranian Lori-Bakhtiari sheep and native goat. Pak. J. Biol. Sci., 10(4):673-5, 2007.

Moreira, E. L. T.; Nascimento, E. F. O. \& Chquiloff, M. A. G. Morphological alterations in the ovaries and uterus of Capra hircus L. I. Regressive alterations. Arq. Esc. Med. Vet. Univ. Fed. Bahia, 14:25-39, 1991.

Sattar, A. \& Khan, M. Z. Incidence and pathology of ovarian diseases of goats. Pak. Vet. J., 8(1):18-21, 1988.

Sisson, S.; Grossman J. D. \& Getty, R. Sisson and Grossman's. The Anatomy of the Domestic Animals. $5^{\text {th }}$ ed. Philadelphia, W. B. Saunders, 1975.

Smith, M. C. Caprine Reproduction. In: Morrow, D. A. (Ed.). Current Therapy in Theriogenology. $2^{\text {nd }}$ ed. Philadelphia, W. B. Saunders, 1986.

Torres, E. B. \& Badiongan, E. H. Postpartum macroscopic changes of the measurements of the reproductive organs of Philippine nondescript goats. Philipp. J. Vet. Anim. Sci., 15(3-4):74-9, 1989.

Correspondence to:

Dr. rer. nat. Ziaul Haque

Associate Professor

Department of Anatomy and Histology

Faculty of Veterinary Science

Bangladesh Agricultural University

Mymensingh - 2202

BANGLADESH

Email: zhaqueah80@gmail.com

Received: 11-05-2015

Accepted: 04-12-2015 